\title{
Immature stages, morphology and feeding behaviour of the saprophytic syrphids Copestylum tamaulipanum and Copestylum lentum (Diptera: Syrphidae)
}

\author{
Ma Angeles MARCOS-GARCÍA and Celeste PÉREZ-BAÑóN \\ Centro Iberoamericano de la Biodiversidad (CIBIO) \\ Departamento de Ciencias Ambientales y Recursos Naturales, Universidad de Alicante, E-03080 Alicante, Spain
}

\begin{abstract}
Key words. Syrphidae, Copestylum tamaulipanum, Copestylum lentum, immature stages, morphology, feeding behaviour, Cactaceae.
\end{abstract}

Abstract. Adults of Copestylum tamaulipanum and C. lentum were reared from larvae collected from decaying platyclades of the
cactus Opuntia in the state of Veracruz (Mexico). The larvae and puparia of both species, as well as preliminary data about their life
cycles are described. The feeding behaviour of the larva in relation to the morphology of the cephalopharyngeal skeleton is analysed.

\section{INTRODUCTION}

The genus Copestylum Macquart, 1846 is endemic to the New World and contains more than 300 species. This genus constitutes, together with Toxomerus Macquart, 1855, Ocyptamus Macquart, 1834, Palpada Macquart, 1834, Microdon Meigen, 1803 and Allograpta Osten Sacken, 1875, the largest syrphid genera in the New World (Vockeroth \& Thompson, 1987). Only four species of Copestylum have been recorded outside the Nearctic and Neotropical regions, three in the Hawaiian Islands: C. apicale (Loew, 1866), C. tamaulipanum (Townsend, 1898) and C. hoya (Curran, 1947) (Vockeroth \& Thompson, 1989), and C. melleum (Jaennicke, 1867) recently recorded from the Canary Islands (Atlantic) (Báez, 2000). Undoubtedly all these species are accidental introductions.

Published rearing records indicate that the larvae of Copestylum develop in various kinds of decaying matter ranging from: saguaro (Cereus giganteus) (Hubbard \& Schwarz, 1899; Sack, 1921; Ryckman \& Ames, 1953; Myles, 1986), rotting banana stumps (Musa cavendisii) (Sack, 1921), paw-paw (Carica papaya) (Greene, 1923) and exudates from Timbo (Enterolobium timbouva) (Sack, 1921). Larvae have also been found in the waterfilled bracts of Heliconia spp. (Seifert \& Seifert, $1976 \mathrm{a}, \mathrm{b})$. Rotting cactus is the food resource for most Copestylum. Many species have been reared from Opuntia spp. in the New World (Johnston, 1921; Sack, 1921; Williams, 1939; Bugbee \& Reigel, 1945; Ryckman \& Ames, 1953; Mann, 1969; Wallace \& Lavallee, 1973; Telford, 1973; Maldonado Capriles \& Berrios, 1977, Zimmerman et. al., 1979; Maier, 1982) however, the life history and the morphology of the immature stages of Copestylum species are poorly known.

Twelve species of Copestylum (some of them considered to be species of Volucella) were described from the immature stages and except for the description of five species: C. mexicanum (Macquart, 1842) (Greene, 1923), C. isabellina (Williston, 1887) and C. apiciferum (Town- send, 1895) (Santana, 1961), C. apicale (Loew, 1866) (Wallace \& Lavallee, 1973) and C. vacuum (Fabricius, 1775) (Maldonado Capriles \& Berrios, 1977), all (Sack, 1921) are superficial and lack sufficient details for comparisons.

Of these 12, only four: C. apicale (Loew, 1866), C. vitatum (Thompson, 1887), C. mexicanum (Macquart, 1842) and C. vacuum (Fabricius, 1775) have been found and reared in rot-pockets of Opuntia species. The two species studied in this paper were found breeding in decaying platyclades of Opuntia species in Veracruz, Mexico, and represent the first biological data on these species.

The objectives of the present study are: 1) to describe the larva (L3) and puparium of Copestylum tamaulipanum (Townsend, 1898) and Copestylum lentum Williston, 1887,2$)$ to compare the immature stages and morphology of the cephalopharyngeal skeleton of all Copestylum species reared on Cactaceae and 3) to present developmental data for these two species.

\section{MATERIAL AND METHODS}

Two adults of C. lentum and seven of C. tamaulipamim were reared from larvae collected on different species of Opuntia growing at different localities in the state of Veracruz (Gulf of Mexico).

Larvae were reared in a growth chamber at $16-22^{\circ} \mathrm{C}, 80-85 \%$ $\mathrm{r}$ h with a constant photo-regime of $15 \mathrm{~L}$ : 9D photoperiod. Plastic cages ( $30 \mathrm{~cm}$ wide, $15 \mathrm{~cm}$ deep, $20 \mathrm{~cm}$ high) containing decaying platyclades of Opuntia were checked daily and L3 instars were placed in a cylindrical plastic cage $(40 \mathrm{~mm}$ high, 80 $\mathrm{mm}$ wide), together with small pieces of dry platyclades, to facilitate pupation. Puparia were placed individually in $55 \mathrm{~mm}$ diameter dishes and inspected daily until the emergence of the adults.

Third instar larvae were selected for preservation. Typically, the larvae of this instar have two discs of differentiated cuticle on the dorsal surface of the first abdominal segment. For permanent preservation, larvae were killed by immersion in cold water and boiled slowly for about four minutes to extend them. Afterwards, they were preserved in $70 \%$ alcohol. 
$\mathbf{A}$

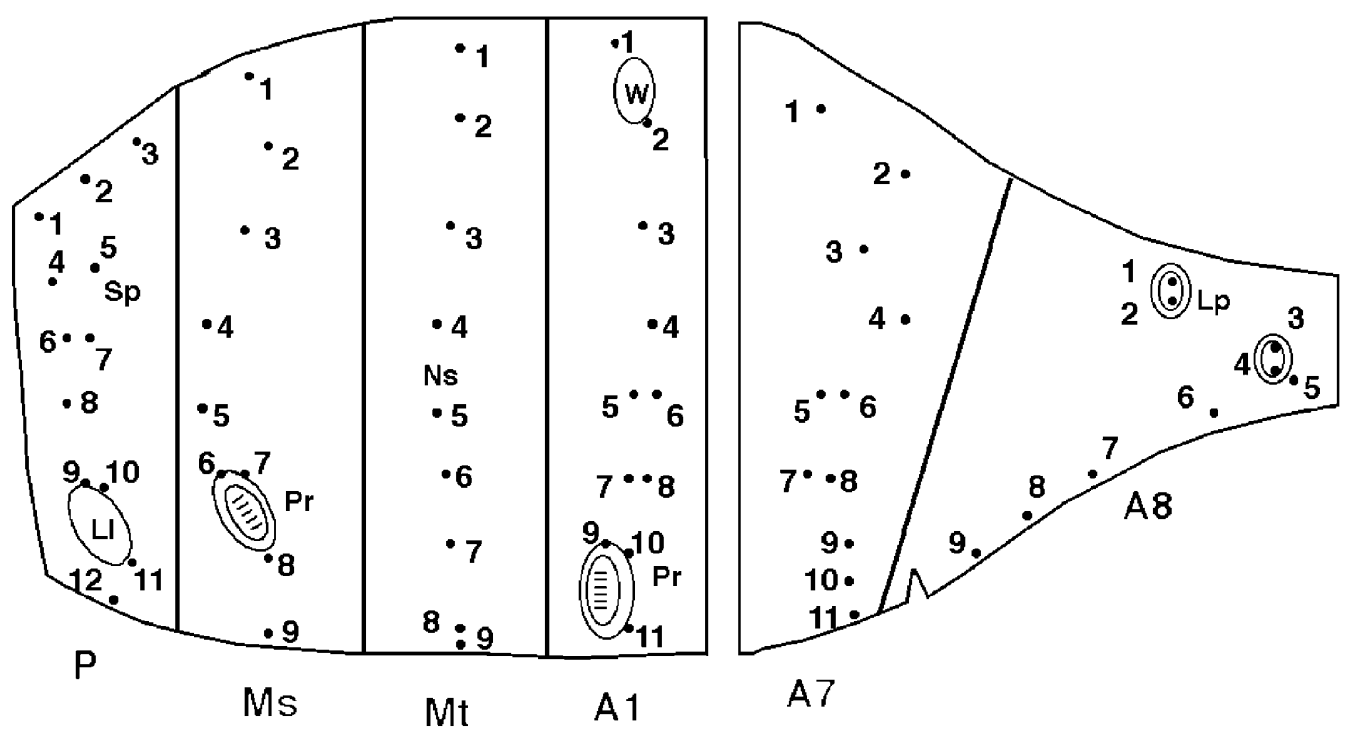

B

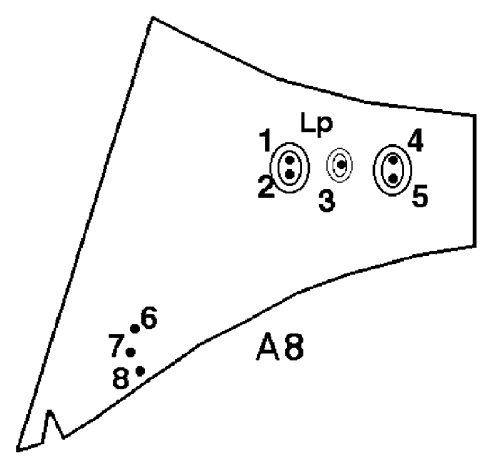

Fig. 1. A - Map of the chaetotaxy of the third instar larva of C. tamaulipanum showing the positions of the groups of sensilla on: P, prothorax; Ms, mesothorax; Mt, metathorax; A1, A7, first and seventh abdominal segments; A8, hind end; Ns, nonfunctional spiracle; L1, lateral lip; Pr, proleg; Sp, anterior functional spiracle; W, area of differentiated cuticule through which the pupal spiracle will be thrust; B - Chaetotaxy of the hind end (A8) of C. lentum.

Descriptions are based on preserved specimens, and the larval characters checked against living specimens in order to minimise errors due to preservation. Illustrations and dimensions (mean \pm standard error) were measured on preserved material using a binocular microscope with an eyepiece micrometer and FSA $25 \mathrm{PE}$ drawing tube. The photographs were taken with a scanning electron microscope (SEM) operated at $20 \mathrm{kV}$.

Terminology used in the descriptions of the larvae follows Hartley (1961) and Rotheray (1993). The positions of the sensilla were numbered sequentially from the dorsal to the ventral surface on each segment (Rotheray, 1991).

The cephalopharyngeal skeletons were removed from the leading ventral edges, of the interior of the puparia, and placed in warm potassium hydroxide $(\mathrm{KOH})$ for 3-4 minutes. Finally they were washed in distilled water and preserved in glycerine until examined. Morphological terminology of this structure follows Hartley (1963).

Voucher specimens of the adult and immature stages of $C$. tamaulipanum and C. lentum are in the Entomological Collection of Alicante University, Smithsonian Institution of Washington and in the National Museum of Scotland.

\section{MATERIAL examined}

\section{Copestylum tamaulipanum (Townsend, 1898)}

Albarado, $6 \mathrm{~m}$, littoral dunes ( $\left.18^{\circ} 46^{\prime} 2^{\prime \prime} \mathrm{N}, 95^{\circ} 45^{\prime} 3^{\prime \prime} \mathrm{W}\right), 5$ males and 2 females reared from larvae collected 24 July 1998 by $\mathrm{M}^{\mathrm{a}} \mathrm{A}$. Marcos-García, in decaying platyclades of Opuntia stricta (Haw) Haw var. dillenii (Ker Gawler) Benson; adults emerged 7 to 13 September 1998.

\section{Copestylum lentum Williston, 1887}

Guadalupe Victoria, Perote, $2380 \mathrm{~m}$, cultivated dry area $\left(19^{\circ}\right.$ $32^{\prime} 5^{\prime \prime} \mathrm{N}, 97^{\circ} 16^{\prime} 8^{\prime \prime} \mathrm{W}$ ). Two males reared from larvae collected 27 July 1998 by $\mathrm{M}^{\mathrm{a}} \mathrm{A}$. Marcos-García, in decaying platyclades of Opuntia huajuapensis Bravo. Adults emerged 18 August 1998.

\section{RESULTS}

\section{Description of the immature stages}

\section{Copestylum tamaulipanum (Townsend, 1898)}

(Figs 2A, 3-4)

Third larval instar (L3)

Length $18.2 \pm 0.62 \mathrm{~mm}$, maximum width $3.1 \pm 0.12$ $\mathrm{mm}(n=6)$. Overall appearance: A short-tailed larva with internal mouth-hooks, bearing two pairs of fleshy lappets 

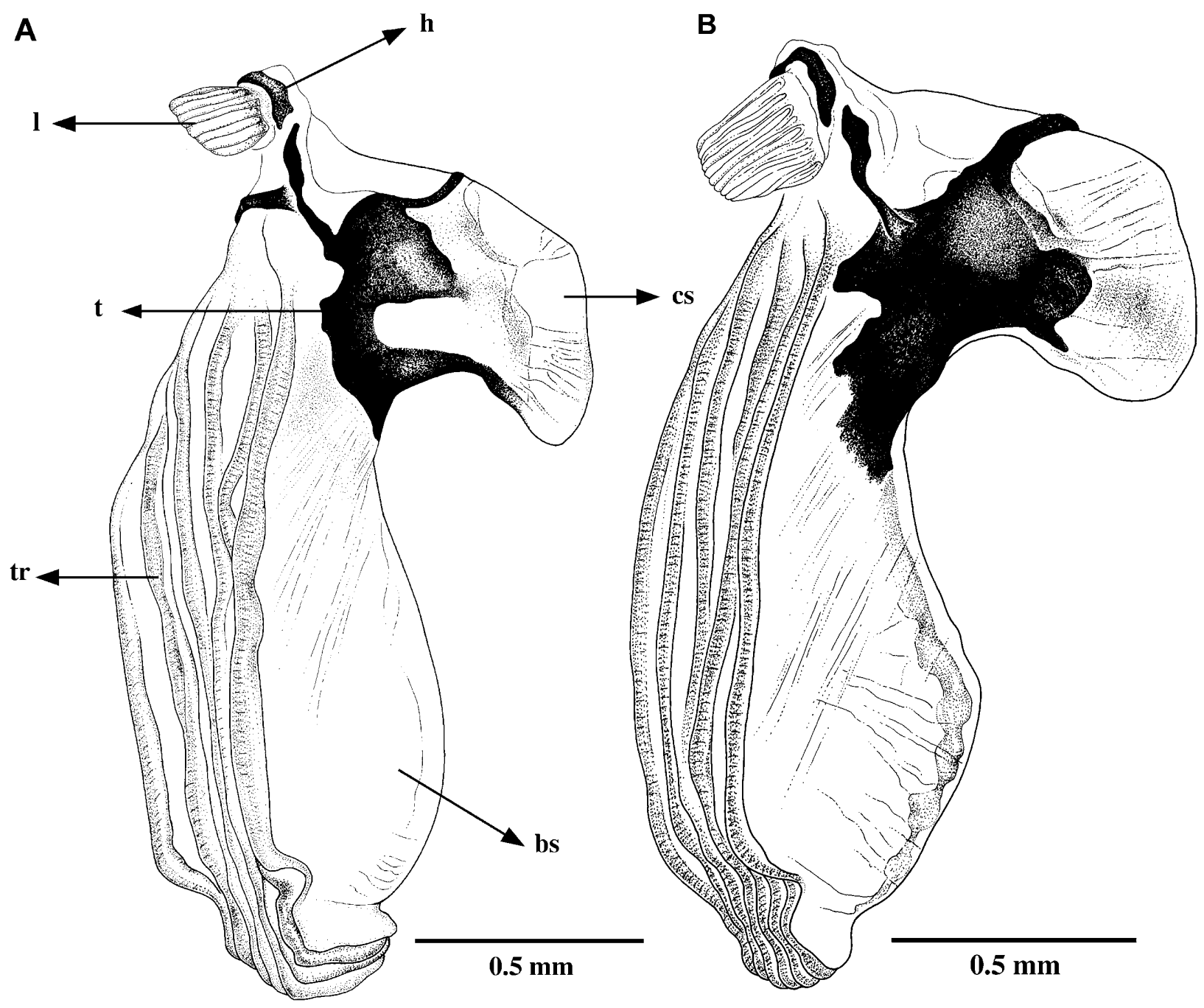

Fig. 2. A - Cephalopharyngeal skeleton of C. tamaulipanum, lateral view: h, mouth-hooks; 1 , mandibular lobes; t, tentorium; cs, clypeal sclerites; bs, basal sclerites; tr, T-ridges; B - Cephalopharyngeal skeleton of C. lentum.

located anterior to the posterior end of the larva. Subcylindrical in cross-section with a flattened ventral surface, slightly truncate anteriorly, and tapering posteriorly. Cuticle translucent when alive, cream to off-white after fixation. Dorsal body surface coated in short, pointed and unpigmented backwardly directed spicules, which are shorter and scarce on the ventral surface except for the anal segment (hind end).

Head. Mouth-hooks (h) and mandibular lobes (l) internal (mouthparts adapted for filter-feeding; Roberts, 1970). Antenno-maxillae organs well developed, maxillary palp as long as antenna, both slightly sclerotised. Cephalopharyngeal skeleton (Fig. 2A): Mouth-hook slightly crescent-shaped, dorsally angular, not sharply pointed nor toothed; mandibular lobes small, about as wide as length of mouthhook, ribbed, with combs of filaments on inner ridges; pharyngeal sclerite with posterior projections: clypeal sclerites (cs) connected by dorsal bridge; these sclerites (cs) are short and strongly pigmented medially and on tentorium (t); basal sclerite (bs) long, narrow and slightly sclerotised. T-ridges (tr) with ribbed cibarial filter.

Thorax. Lateral lips rounded and well developed (in profile projecting forward from the anterior part of the prothorax), and coated in long and fine unpigmented setae (Fig. 3B). Dorsal lip coated in very short, pointed and sclerotised spicules. Anterior fold on dorsal surface of the prothorax with longitudinal grooves and narrow band ( $<30 \%$ of anterior fold) of densely aggregated, backwardly directed, sclerotised spicules that become progressively shorter posteriorly. Dorsal surface of the prothorax with anterior respiratory process sclerotised, short and trilobed apically. Lateral margin of prothorax (P) with two patches of sclerotised spicules arranged as follows: a group of 15-20 just anterior to 4th sensilla of mesothorax (Ms) and another prothoracic group of 15-20 spiculae is located in front of the 5th sensillia of mesothorax (Fig. 1). Dorsal surface of mesothorax with a patch of 15 sclerotized spicules behind anterior respiratory process. Mesothorax bearing well developed prolegs with about 50 crochets each arranged in two semicircular 

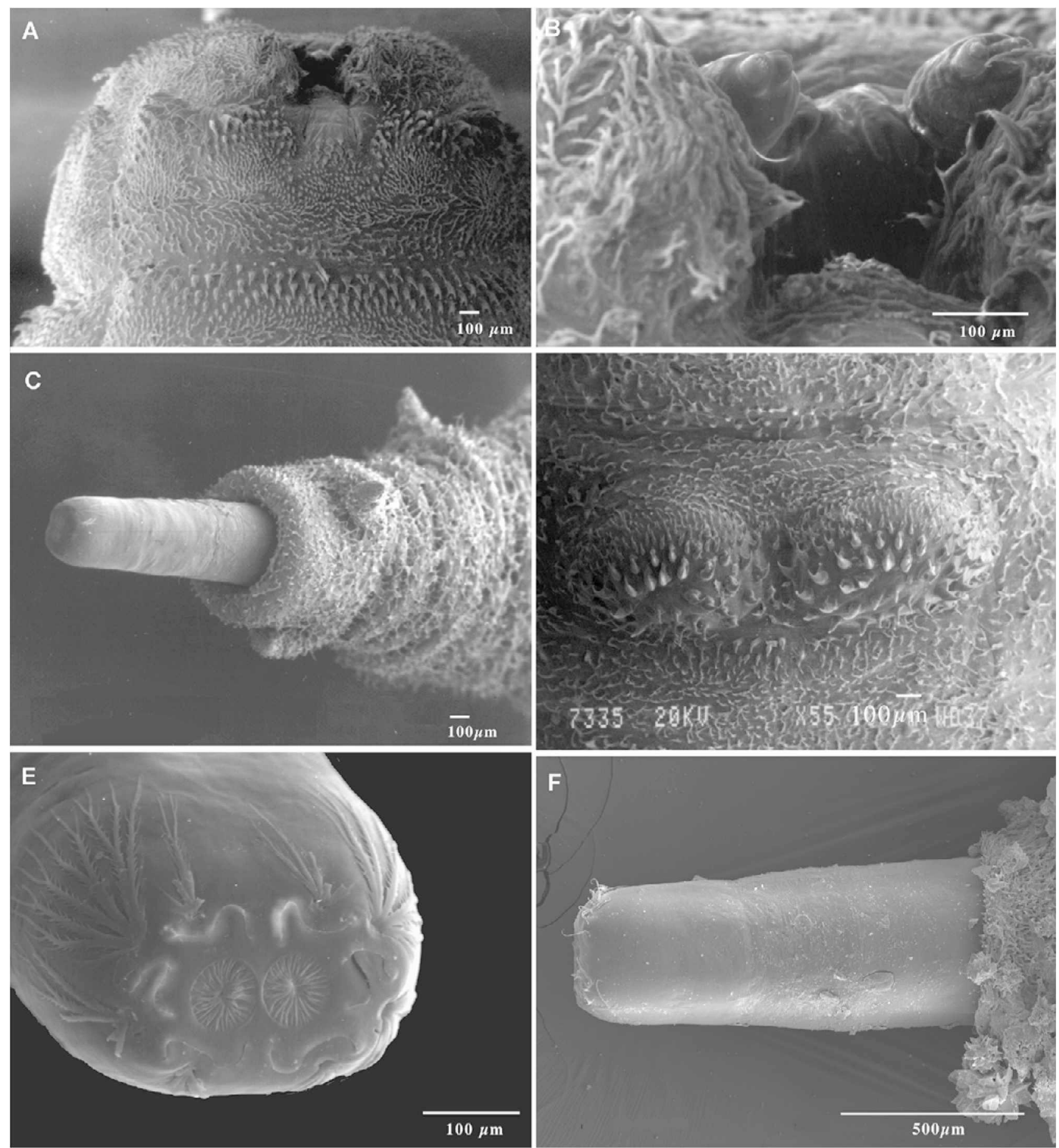

Fig. 3. Larva of C. tamaulipanum: A - Ventral view of prothorax, mesothorax and metathorax; B - Antenno-maxillary organs and mandibular lobes; C - Abdominal prolegs. D - Anal segment of larva showing two pairs of lappets; E - Spiracular plate of the posterior respiratory process; $\mathrm{F}$ - Dorsal view of the posterior respiratory process.

groups (Fig. 3A). Ventral surface of metathorax (Mt) with a narrow band bearing about $80-85$ small and slightly sclerotized crochets (Fig. 3A).

Abdomen. Primordia of pupal spiracles obvious on the dorsal surface of first abdominal segment. Ventral prolegs (Pr) small and multi-serial, 6 abdominal pairs on segments 1-6. Each proleg with 35-38 brown crochets. Central crochets slightly bigger than the anterior and posterior ones, all of which are directed posteriorly (Fig. 3C). Anal segment with two pairs of fleshy lappets, posterior pair located ventrolaterally, just anterior to base of the posterior respiratory process (prp); second and smaller pair located dorsolaterally and anterior to preceding pair (Fig. 3D).

Posterior respiratory process (prp) (stigmatophore). Length $1.3 \pm 0.14 \mathrm{~mm}$; width: at base $0.42 \pm 0.008 \mathrm{~mm}$, at tip $0.29 \pm 0.006 \mathrm{~mm} ;(n=6)$. Shiny, sclerotised and brown in colour. Spiracular plates fused into a single 

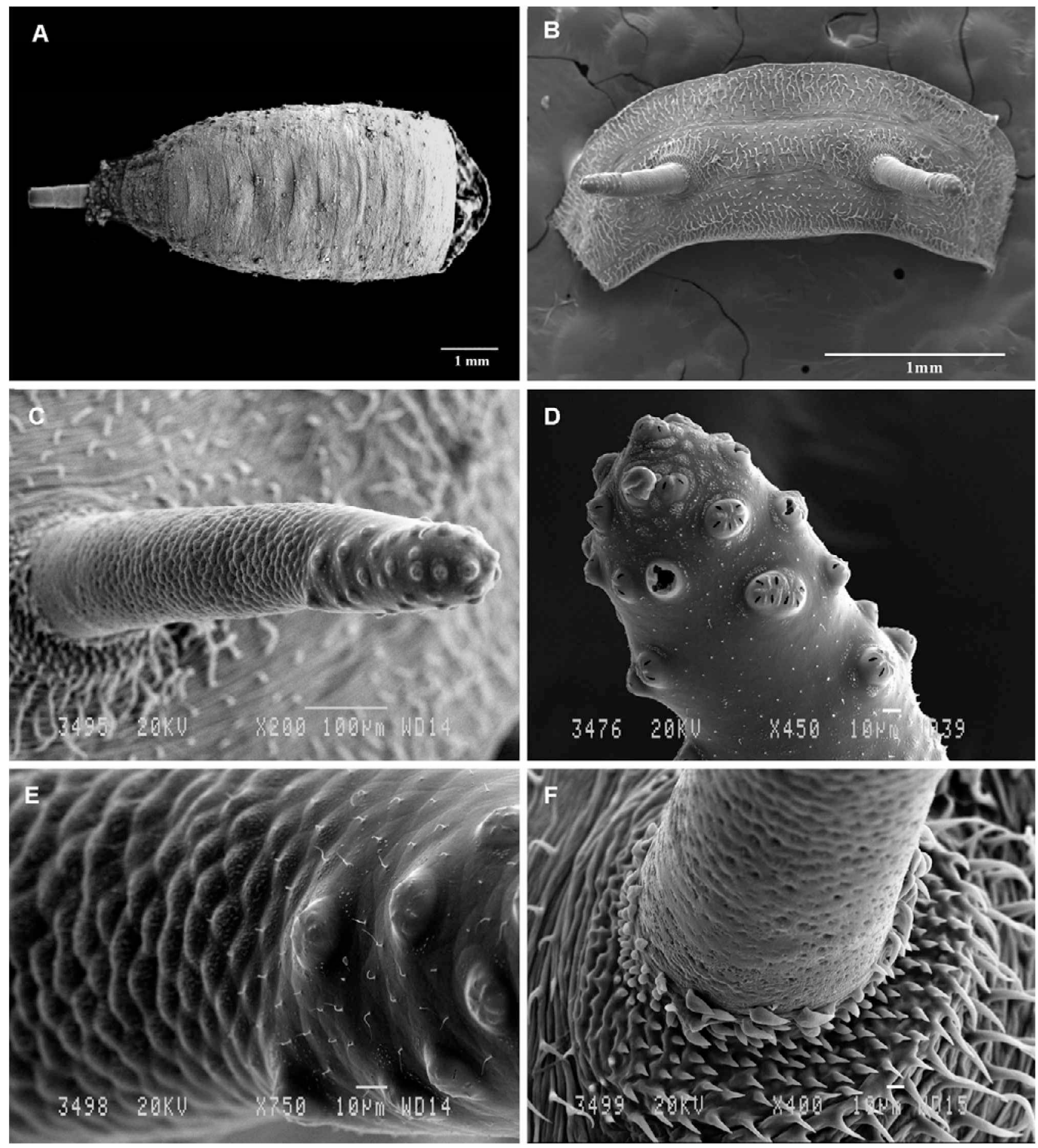

Fig. 4. Puparium of C. tamaulipanum. A - Puparium, dorsal view; B - Operculum with pupal respiratory processes; C - Thoracic respiratory process; $\mathrm{D}$ - Spiracular openings of thoracic respiratory process; $\mathrm{E}$ - Ornamentation of base of thoracic respiratory process; F - Base of thoracic respiratory process.

plate slighty constricted medially. Six spiracular slits each with a clearly sinuous shape arranged around two central scars (Fig. 3E). Periphery with four pairs of long and plumose spiracular setae with at least five basal branches. Surface of posterior respiratory process smooth and shiny (Fig. 3F).

Chaetotaxy. Prothorax (P) with 12 pairs of sensilla; mesothorax (Ms) and metathorax (Mt) with 9 pairs; abdominal segments $1-7$ with 11 pairs; anal segment with 9 pairs (Fig. 1).

\section{Puparium}

Length including posterior respiratory process $8.2 \pm$ $0.21 \mathrm{~mm}$, maximum width $3.14 \pm 0.09 \mathrm{~mm}(n=7)$. Subcylindrical in cross-section (Fig. 4A). Anterior extremely 

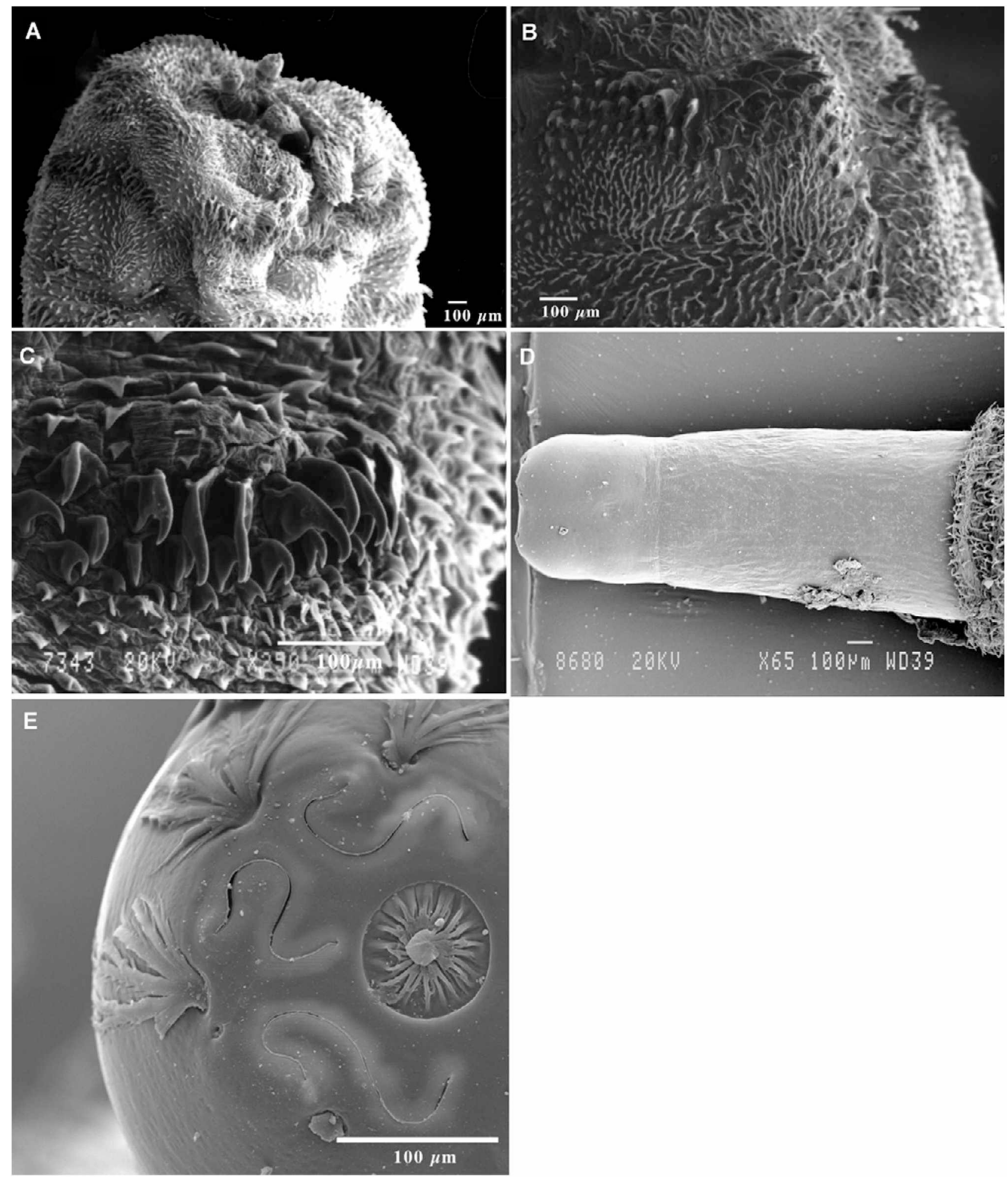

Fig. 5. Larva of C. lentum. A - Ventral view of prothorax, mesothorax and metathorax; B - Mesothoracic prolegs; C Abdominal prolegs; D - Dorsal view of the posterior respiratory process; E - Spiracular slits of the posterior respiratory process.

truncated, tapered posteriorly and flattened ventrally. Integument rough, with segmentation of larvae persisting as transverse folds and wrinkles. Brown in colour. Ventral surface with prolegs visible on mesothorax and first 6 abdominal segments. Dorsally, two thoracic respiratory processes protrude on the upper half of the operculum, they are sep rated by a distance of about one and half time their length (Fig. 4B). These processes are subcylindrical structures of about $0.8 \mathrm{~mm}$ in length, bearing a crown of irregularly-spaced and rounded tubercles usually extending no more than a third of the way down the upper surface (Fig. 4C). Surface between tubercles smoothly-polished with very fine short and scattered setae, except around apical tubercules where it is finely 

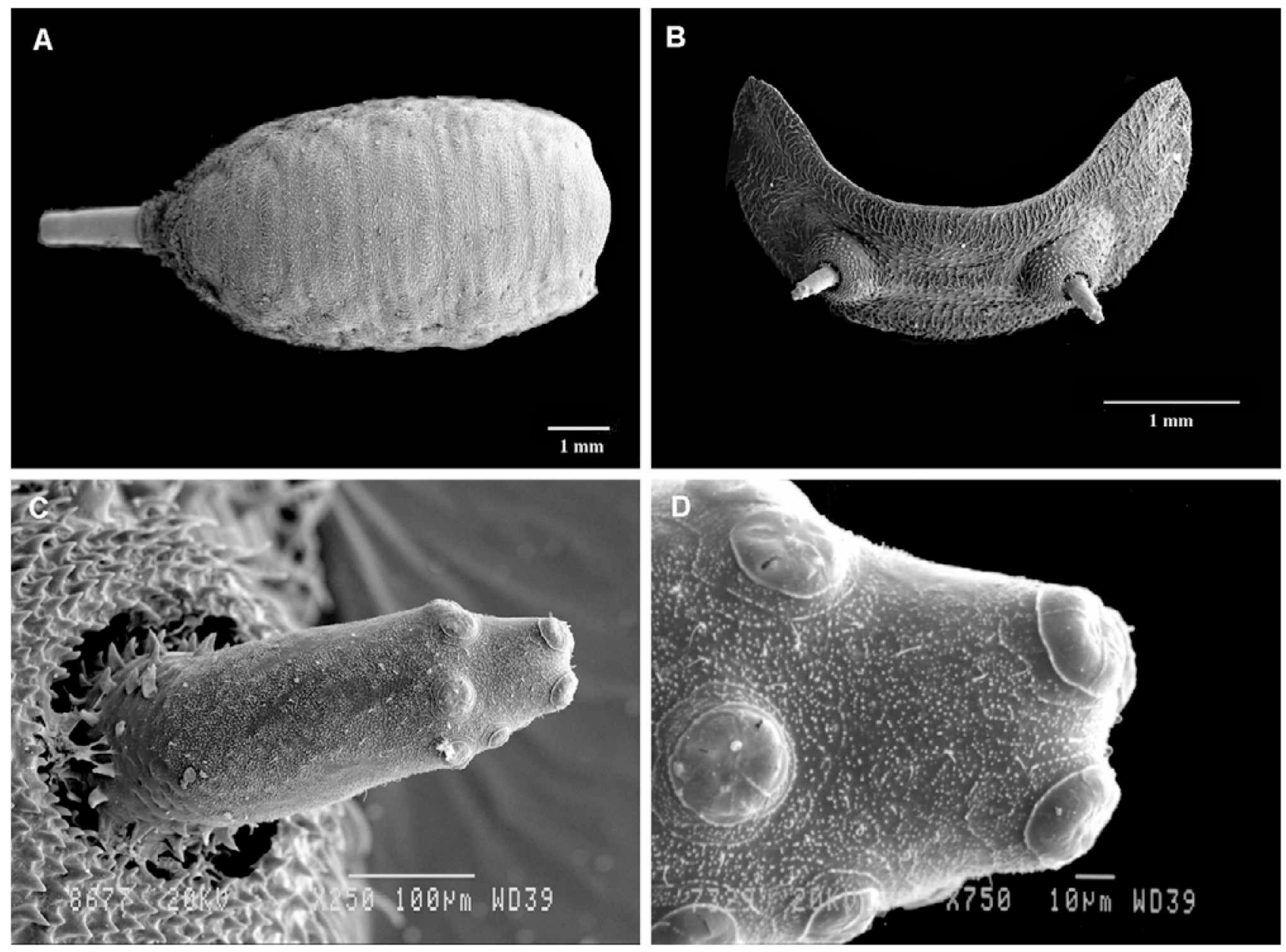

Fig. 6. Puparium of C. lentum. A - Puparium, dorsal view; B - Operculum with pupal respiratory processes; C - Thoracic respiratory process; D - Spiracular openings of thoracic respiratory process.

beaded (Fig. 4D). Each tubercle has from 2 to 5 oval openings (Fig. 4D). Basal part of the thoracic respiratory processes with a granular surface (Fig. 4E). Base of the processes encircled by pointed spicules (Fig. 4F).

\section{Copestylum lentum Williston, 1887}

(Figs 2B, 5-6)

Third larval instar (L3)

Length (tip of prothorax to apex of the posterior respiratory process) $15.3 \pm 1.76 \mathrm{~mm}$; maximum width $3.6 \pm$ $1.33 \mathrm{~mm}(n=3)$. Overall appearance: A short-tailed larva with internal mouth-hooks, bearing three pairs of fleshy lappets, second pair reduced to just sensilla and surrounding setae, and first and third of similar size. Subcylindrical in cross-section with a flattened ventral surface, truncate anteriorly, and slightly tapering posteriorly. Cuticle translucent when alive, cream to off-white after fixation. Dorsal body surface coated in short, pointed and unpigmented spicules backwardly directed that are shorter on the ventral surface except those on the anal segment.

Head. Mouth-hooks (h) and mandibular lobes (1) internal (mouthparts adapted for filter-feeding; Roberts, 1970). Antenno-maxillae organs well developed, maxillary palp as long as antenna, both slightly sclerotised.
Cephalopharyngeal skeleton (Fig. 2B): Mouthhook weakly crescent-shaped, dorsally slightly curved, not sharply pointed nor toothed; mandibular lobes large, at least twice as wide as length of mouthhook, ribbed, with combs of filaments on inner ridges; posteriorly projecting pharyngeal sclerite: clypeal sclerites (cs) connected by dorsal bridge; these sclerites (cs) are short and strongly pigmented medially and on tentorium $(\mathrm{t})$; basal sclerite (bs) long, and slightly sclerotised. T-ridges (tr) with ribbed cibarial filter.

Thorax. Lateral lips rounded and well developed (in profile projecting forward from the anterior part of the prothorax) and coated in long and fine unpigmented setae. Dorsal lip coated in very short, pointed and sclerotised spicules (Fig. 5A). Anterior fold on dorsal surface of the prothorax with longitudinal grooves and narrow band ( $<45 \%$ of anterior fold) of densely aggregated, backwardly directed, sclerotised spicules that become progressively shorter posteriorly. Anterior respiratory processes lacking, their position marked by two minute, circular areas on dorsal surface of the prothorax. Lateral margin of mesothorax (P) with two patches of sclerotised spicules arranged as follows: a group of 20-25 just anterior to 4th sensilla of mesothorax (Ms) and another prothoracic 
group of 13-18 spiculae located in front of the 5th sensilla of mesothorax. Dorsal surface of mesothorax with a patch of 20-25 sclerotised spicules anterior to 1 st and 2 nd mesothoracic sensilla. Lateral margin of metathorax (Mt) with one group of 10-12 sclerotised spicules surrounding 4th sensillum of metathorax and another group of 6-10 spiculae located in front of the 5th sensillum. Mesothorax bearing well developed prolegs with about 35-40 crochets, arranged in 3-4 rows (Fig. 5B). Space between prolegs covered in small and sclerotised spicules. Ventral surface of metathorax with a narrow band bearing about 70-75 small and slightly sclerotised crochets.

Abdomen. Primordia of pupal spiracles obvious on dorsal surface of first abdominal segment. Ventral prolegs (Pr) small, 6 abdominal pairs on segments 1-6. Each proleg with 2 or 3 rows of apically brown crochets: 7 or 9 primary, 7 or 9 secondary and some tertiary (Fig. 5C), except on the last abdominal segment where they are absent or reduced in number. Crochets in anterior row slightly bigger than posterior ones. Anal segment with three pairs of fleshy lappets, second pair located ventrolaterally and reduced to just sensilla and surrounding setae, first pair located dorsolaterally and the third pair placed ventrolaterally, just anterior to base of the posterior respiratory process (prp).

Posterior respiratory process (prp) (stigmatophore).

Length $1.1 \pm 0.09 \mathrm{~mm}$; width: at base $0.61 \pm 0.008 \mathrm{~mm}$, at tip $0.47 \pm 0.014 \mathrm{~mm} ;(n=3)$. Shiny, sclerotised and brown in colour. Spiracular plates fused into a single plate constricted medianly. Six spiracular slits with a clearly sinuous shape arranged around two central scars (Fig. 5E). Periphery with four pairs of long and plumose spiracular setae with at least, five basal branches. Basal two-thirds of the posterior respiratory process finely ridged to just below the smooth and shiny tip (Fig. 5D).

Chaetotaxy. Prothorax (P) with 12 pairs of sensilla; mesothorax (Ms) and metathorax (Mt) with 9 pairs; abdominal segments $1-7$ with 11 pairs; anal segment with 8 pairs (Fig. 1).

\section{Puparium}

Length including posterior respiratory process $8-9 \mathrm{~mm}$, maximum width 3-4 $\mathrm{mm}(n=2)$. Subcylindrical in cross section. Anterior extremely truncated, tapered posteriorly and flattened ventrally (Fig. 6A). Integument rough, with segmentation of larvae persisting as transverse folds and wrinkles. Brown in colour. Ventral surface with prolegs visible on mesothorax and first 7 abdominal segments. Dorsally, the two thoracic respiratory processes protrude on the upper half of the operculum, they are separated by a distance of about four times their length (Fig. 6B). These processes are sub-cylindrical structures of about $0.4 \mathrm{~mm}$ in length, bearing a crown of irregularly-spaced rounded tubercles usually extending no more than a quarter of the way down the upper surface (Fig. 6C). The base is entirely encircled with irregularly spaced and pointed spicules (Fig. 6C). Entire surface, including spaces between tubercles, finely beaded, some of these minute projections bear a single apical seta (Fig. 6D). Each tubercle has from 4 to 6 oval apertures (Fig. 6D).

\section{Biological data}

Larvae of $C$. lentum and C. tamaulipanum were found inside decaying platyclades that characteristically occur on the branches of Opuntia, and in detached and fallen platyclades. The necrotic areas of these platyclades seem to be produced by microorganismes, maybe a bacterium like that causing the bacterial necroses on the giant saguaro (Cereus giganteus Engl.) (Lightle et al., 1942). The infected region, still covered by the epidermis, becomes water-logged with the destruction of the internal tissues. The necrotic tissue continues to desintegrate, and at the final stage of decay it may become spongy and eventually dry out. The larvae of these two species of Copestylum were found mainly during the later stages of decay when the most of the internal tissues have been reduced to a syrupy malodorous liquid.

Generally, damaged platyclades shelter numerous larvae of the same species of Copestylum together with other larvae of Stratiomyidae. Pupation took place on the dry parts of platyclades where the process of decay was complete.

Pupal period was similar in the 2 species of Copestylum: 7-11 days for C. tamaulipanum $(\mathbf{n}=7)$ and 10-11 days for C. lentum $(\mathrm{n}=2)$.

\section{DISCUSSION}

Only the immature stages of a few species of Copestylum have been described in detail. Based on the descriptions in the literature and our morphological study of the immature stages of $C$. lentum and $C$. tamaulipanum, we can conclude that the overall appearance of the larvae of Copestylum is characterised by: a short-tail, sub-cylindrical in cross-section; mouth-hooks and mandibular lobes internal; prothorax with a band of sclerotised spicules on the anterior fold; prolegs with crochets arranged in a transverse row; anal segment with lappets.

As is to be expected, the larvae of Copestylum that breed in decaying Cactaceae show striking similarities. However, close examination revealed differences between the species. Therefore, the larvae of the genus Copestylum that breed in decaying Cactaceae may be distinguished by the following characteristics: (1) presence or absence of anterior spiracles; (2) number and relative size of the lappets on the anal segment; (3) shape and ornamentation of the posterior respiratory process and (4) size of the mandibular lobes in relation to the length of the mouthhook (Table 1).

For the puparium, the main diagnostic characters are summarized in Table 2: shape and ornamentation of thoracic respiratory processes and distance between thoracic respiratory processes.

Decaying cactus, whether prickly pear or other species, is a very suitable breeding ground for saprophagous syrphids, mainly Copestylum species but also some species of Nausigaster Williston, 1883 (Hunter et al., 1912; Rotheray et all., 2000.), Eumerus Meigen, 1822 and Syritta Lepeletier \& Serville, 1828 (Pérez-Bañón \& Marcos-García, 1998; 2000). These syrphids are attracted 
TABLE 1. Comparison of the main morphological characters of third-instar larvae of Copestylum species breeding on decaying cactus.

\begin{tabular}{|c|c|c|c|c|}
\hline \multirow[b]{2}{*}{ Species } & \multicolumn{4}{|c|}{ Character of third-instar Copestylum larva } \\
\hline & Anterior spiracles & $\begin{array}{c}\text { Lappets (projection } \\
\text { around the anal } \\
\text { segment) }\end{array}$ & Mandibular lobes & $\begin{array}{c}\text { Shape and ornamenta- } \\
\text { tion of posterior respira- } \\
\text { tory processes }\end{array}$ \\
\hline C. tamaulipanum & present, trilobed apically & $\begin{array}{l}2 \text { pairs well developed } \\
\text { (apical pair of lappets } \\
\text { bigger than anterior pair) }\end{array}$ & $\begin{array}{l}\text { small (about as wide } \\
\text { as length of mouthhook) }\end{array}$ & $\begin{array}{l}\text { edges of spiracular plate } \\
\text { rounded and smooth }\end{array}$ \\
\hline C. lentum & absent & $\begin{array}{l}3 \text { pairs, second pair } \\
\text { reduced to just a sensilla } \\
\text { and surronding setae }\end{array}$ & $\begin{array}{l}\text { large (at least twice as } \\
\text { wide as length of } \\
\text { mouthhook ) }\end{array}$ & $\begin{array}{l}\text { edges of spiracular plate } \\
\text { rounded and smooth }\end{array}$ \\
\hline C. apicale & present, trilobed apically & $\begin{array}{l}2 \text { pairs well developed } \\
\text { (apical pair of lappets } \\
\text { bigger than anterior pair) }\end{array}$ & $\begin{array}{l}\text { large (at least twice as } \\
\text { wide as length of } \\
\text { mouthhook) }\end{array}$ & $\begin{array}{l}\text { edges of spiracular plate } \\
\text { rounded and smooth }\end{array}$ \\
\hline C. vacuum & present, bilobed apically & $\begin{array}{l}2 \text { pairs well developed } \\
\text { (apical pair of lappets } \\
\text { bigger than anterior pair) }\end{array}$ & $\begin{array}{l}\text { large (one and half } \\
\text { time as wide as length } \\
\text { of mouthhook) }\end{array}$ & $\begin{array}{l}\text { edges of spiracular plate } \\
\text { rounded and smooth }\end{array}$ \\
\hline $\begin{array}{l}\text { C. apiciferum } \\
\text { (as V. clarki) }\end{array}$ & absent & $\begin{array}{l}3 \text { pairs well developed } \\
\text { (apical pair of lappets } \\
\text { bigger than anterior ones) }\end{array}$ & ++ & $\begin{array}{l}\text { edges of spiracular plate } \\
\text { rounded and smooth }\end{array}$ \\
\hline $\begin{array}{l}\text { C. isabellina } \\
\text { (as } V \text {. isabellina) }\end{array}$ & present, trilobed apically & $\begin{array}{l}3 \text { pairs well developed } \\
\text { and of a similar size }\end{array}$ & ++ & $\begin{array}{l}\text { spiracular plate encircled } \\
\text { by a carina of short and } \\
\text { prominent denticles }\end{array}$ \\
\hline $\begin{array}{l}\text { C. spinigera } \\
\text { (as Temnocera } \\
\text { spinigera) }\end{array}$ & present & $\begin{array}{l}2 \text { pairs well developed } \\
\text { (apical pair of lappets } \\
\text { bigger than anterior one) }\end{array}$ & ++ & ++ \\
\hline $\begin{array}{l}\text { C. mexicanum } \\
\text { (as V.nigra) }\end{array}$ & present & 3 pairs well developed & ++ & $\begin{array}{l}\text { spiracular plate } \\
\text { encircled by a series of } \\
\text { narrow wrinkles }\end{array}$ \\
\hline
\end{tabular}

++ Characters not described

to cactus joints that are damaged by another insects, mainly Lepidoptera, boring beetles, or are attacked by bacterial and fungus diseases (Bugbee \& Reigel, 1945; Santana, 1961; Mann, 1969).

The morphology of the cephalopharyngeal skeleton of C. lentum and C. tamaulipanum (Fig. 2A and 2B) accords well with their feeding habits, both species have well developed ventral pharyngeal ridges. The ventral pharyngeal ridges select the appropriate food particle size, permitting partial digestion before swallowing of the particles and increasing efficiency of food utilisation by its concentration (Roberts, 1969). The cephalopharyngeal skeleton of the two species described here are very similar and also show striking similarities with the cephalopharyngeal skeleton of C. vacuum (Fabricius, 1775) (the only Copestylum species whose cephalopharyngeal skeleton has been described). These striking similarities may be explained by the absence of differences in diet between these taxa.

The other mouthparts of the larva of $C$. lentum and $C$. tamaulipanum are very similar to those of other saprophagous syrphids such as Eristalis Latreille, 1804, Brachyopa Meigen, 1822, Chrysogaster Meigen 1803, Xylota Meigen, 1822 etc. which feed by filtering microorganisms from fluids. For example, in all these taxa: the thorax is broad and the anterior fold is coated in spicules; the dorsal lip is firm not fleshy; the lateral lips are large and coated in variously sized setae; the mandibular lobes are large, consisting of numerous ridges. The functional significance of this morphology appears to be for imbibing and filtering food particles suspended in fluids and expelling the filtered fluid (Rotheray, 1993).

Nevertheless, the food channel, a depressed region posterior to the mouth, is lacking in the two species here described. This food channel is a particular feature of saprophagous syrphids developing in liquid media. It is also absent in Syritta larvae reared on Opuntia spp., which may be related to the different density of the medium, as the decaying platyclades of Cactaceae offer a thick substratum, which is not completely fluid.

ACKNOWLEDGEMENTS. We thank F. Ch. Thompson for the identification of our reared specimens and G. Rotheray for critically reviewing an earlier draft of this manuscript. Illustrations were kindly produced by Alma B. Gámez. Financial support was provided by the Ecology Institute of Xalapa, Veracruz, México (Research Programme CONABIO N $\mathrm{N}^{\circ} \mathrm{K} 038$ ) and the Spanish Ministerio de Ciencia y Tecnología (BOS2000-0148). 
TABLE 2. Comparison of the main morphological characters of puparia of Copestylum species breeding on decaying cactus.

\begin{tabular}{|c|c|c|c|}
\hline \multirow[b]{2}{*}{ Species } & \multicolumn{3}{|c|}{ Characters of Copestylum puparium } \\
\hline & $\begin{array}{l}\text { Shape of } \\
\text { thoracic } \\
\text { respiratory }\end{array}$ & $\begin{array}{l}\text { Separation between } \\
\text { thoracic respiratory } \\
\quad \text { processes }\end{array}$ & Ornamentation of thoracic respiratory processes \\
\hline C. tamaulipanum & straight & $\begin{array}{l}\text { about one and half } \\
\text { time the length of } \\
\text { one spiracle }\end{array}$ & $\begin{array}{l}\text { a crown of irregularly-spaced and rounded tubercles usually } \\
\text { extending no more than a third of the way down the upper surface } \\
\text { (Fig. 4C). Surface between tubercles smoothly-polished. Basal } \\
\text { part of the thoracic respiratory processes with a granular surface } \\
\text { (Fig. 4E). }\end{array}$ \\
\hline C. lentum & straight & $\begin{array}{l}\text { about four times the } \\
\text { length of } \\
\text { one spiracle }\end{array}$ & $\begin{array}{l}\text { a crown of irregularly-spaced rounded tubercles usually extending } \\
\text { no more than a quarter of the way down the upper surface (Fig. } \\
6 \mathrm{C} \text { ). Entire surface finely beaded, some of these minute projec- } \\
\text { tions bear a single apical seta (Fig. 6D) }\end{array}$ \\
\hline C. apicale & straight & ++ & ++ \\
\hline C. vacuum & straight & ++ & ++ \\
\hline $\begin{array}{l}\text { C. apicerferum } \\
\text { (V. clarki) }\end{array}$ & straight & $\begin{array}{l}\text { twice the length of one } \\
\text { spiracle }\end{array}$ & $\begin{array}{l}\text { a crown of irregularly-spaced rounded tubercles usually extending } \\
\text { no more than a third of the way down the upper, or posterior, sur- } \\
\text { face. Entire surface finely beaded, each minute projection bears a } \\
\text { single apical seta }\end{array}$ \\
\hline $\begin{array}{l}\text { C. isabellina } \\
\text { (as V. isabellina) }\end{array}$ & straight & length of one spiracle & $\begin{array}{l}\text { anterior face of horns smoothly -polished, apical portion crowned } \\
\text { with conical, spike-like tubercles radiating out in all directions, } \\
\text { decreasing in size to numerous rounded tubercles as they descend } \\
\text { from the posterior or upper surface }\end{array}$ \\
\hline $\begin{array}{l}\text { C. spinigera } \\
\text { (as Temno- } \\
\text { cera spinigera) }\end{array}$ & $\begin{array}{l}\text { slightly turned } \\
\text { upward }\end{array}$ & $\begin{array}{l}\text { half the length of a } \\
\text { spiracle }\end{array}$ & tubercles in raised 5-6 annular bands \\
\hline $\begin{array}{l}\text { C. mexicanum } \\
\text { (as } V . \text { nigra) }\end{array}$ & $\begin{array}{l}\text { slightly turned } \\
\text { upward }\end{array}$ & $\begin{array}{l}\text { twice the length of a } \\
\text { spiracle }\end{array}$ & $\begin{array}{l}\text { front surface bare. The upper and lateral surface with nunerous, } \\
\text { large, round tubercles. Basal part of the thoracic respiratory proc- } \\
\text { esses with a granular surface }\end{array}$ \\
\hline
\end{tabular}

++ Characters not described

\section{REFERENCES}

BÁEz M. 2000: Nuevas citas de dípteros e himenópteros para las Islas Canarias (Insecta: Diptera: Hymenoptera). Bol. Asoc. esp. Ent. 24 (1-2): 179-183.

Bugbee R.E. \& Reigel A. 1945: The Cactus Moth, Melitara dentata (Grote), and its effect on Opuntia macrorrhiza in Western Kansas. Am. Mid. Nat. 33: 117-127.

Greene C.T. 1923: A new species of Volucella (Diptera). Proc. Ent. Soc. Wash. 25: 165-168.

HARTLEY J.C. 1961: A taxonomic account of the larvae of some British Syrphidae. Proc. R. Entomol. Soc. London 33: 505-573.

HARTLEY J.C. 1963: The cephalopharyngeal apparatus of Syrphid larvae and its relationships to other diptera. Proc. Zool. Soc. Lond. 141: 261-280.

Hubbard H.G. \& Schwarz E.A. 1899: Insect fauna of the giant cactus of Arizona: Letters from the Southwest. Psyche Suppl. 1: $1-14$.

Hunter W.D., Pratt F.C. \& Mrtchell J.D. 1912: The principal cactus insects of the United States. U.S. Department of Agriculture, Bureau of Entomology, Bulletin 113: 1-71.

JoHNSTON T.H. 1921: Biological control of the prickly-pear pest. Queensland Agric. J. 16 (2): 65-68.

Lightle P.C., Standring, E.T. \& Brown J.G. 1942: A bacterial necrosis of the giant cactus. Phytopathology 32: 303-313.

MAIER C.T. 1982: Larval habitat and mate-seeking sites of flower flies (Diptera: Syrphidae: Eristalinae). Proc. Ent. Soc. Wash. 84: 603-609.
MANN J. 1969: Cactus-feeding insects and mites. Bull. US Nat. Mus. 256: 1-158.

Myles T.G. 1986. Oviposition and development of Volucella isabellina (Diptera: Syrphidae) on Saguaro cactus, Cereus giganteus. Ent. News 97: 104-108.

Maldonado Capriles J. \& Berrios A. 1977: The immature stages of Copestylum vacuum (F.) (Diptera: Syrphidae). A new record for Puerto Rico. J. Agr. Univ. Puerto Rico 61: 395-399.

Pérez-Bañón C. \& Marcos-García M M A. 1998: Life history and description of the immature stages of Eumerus purpurariae (Diptera: Syrphidae) developing in Opuntia maxima. Eur. J. Entomol. 95: 373-382.

Pérez-Bañón C. \& Marcos-García M ${ }^{a}$ A. 2000: Description of the immature stages of Syritta flaviventris (Diptera: Syrphidae) and new data about the life history of European species of Syritta on Opuntia maxima. Eur. J. Entomol. 97: 131-136.

RyCKMAN R.E. \& AMES C.T. 1953: Insects reared from cacti in Arizona. Pan-Pacific Entomol. 60: 326-331.

RoBerts M.J. 1969: The feeding habits of higher dipteran larvae. Entomologist 102: 99-106.

RoBerTs M.J. 1970: The structure of the mouthparts of syrphid larvae (Diptera) in relation to feeding habits. Acta Zoologica 51:43-65.

RotheraY G.E. 1991: Larval stages of 17 rare poorly known British hoverflies (Diptera: Syrphidae). J. Nat. Hist. 25: 945-969. 
RotherAy G.E. 1993: Colour Guide to Hoverfly Larvae (Diptera, Syrphidae) in Britain and Europe. Dipterist Digest No. 9, Sheffield, $156 \mathrm{pp}$.

Rotheray G.E., Marcos-García M.A., Hancock E.G. \& GilBERT F.S. 2000: The systematic position of Alipumilio and Nausigaster based on early stages (Diptera: Syrphidae). Studia Dipterologica 7: 133-144.

SACK P. 1921: Dr. L. Zurcher's Dipteren-Ausbeute aus Paraguay. Archiv für Naturgeschichte 87: 127-149.

SANTANA F.J. 1961: The Biology of Immature Diptera Associated with Bacterial Decay in the Giant Saguaro Cactus (Cereus giganteus Englemann). MS Thesis, University Arizona, Tuscon, pp. 1-60.

SeIfert R.P. \& SeIFert F.H. 1976a: A Heliconia insect community in a Venezuelan cloud forest. Ecology 60: 462-467.

SEIFERT R.P.\& SEIFERT F.H. 1976b: Natural history of insects living in inflorescences of two species of Heliconia. New York Entomological Society 84: 233-242.

Telford H.S. 1973: The Syrphidae of Puerto Rico. J. Agr. Univ. Puerto Rico 57: 217-246.
Vockeroth J.R. \& ThOMPSON F.C. 1987: Syrphidae. In McAlpine J. F. (ed.): Manual of Nearctic Diptera Vol. 2. Research Branch Agriculture Canada, Hull (Quebec), pp. 713-743.

Vockeroth J.R. \& Thompson F.C. 1989: Syrphidae. In Evenhuis, N. L. (ed.): Catalog of the Diptera of the Australasian and Oceanian Regions. Bishop Museum Press \& E.J. Brill, Honolulu, pp. 437-458.

WALLACE J.B. \& LAVALLEE A.G. 1973: Immature stages of Milesiinae (Syrphidae) 1: Cheilosia pallipes and Volucella apicalis. J. Georgia Ent. Soc. 8: 187-194.

Williams F.X. 1939: Biological studies in Hawaiian waterloving insects. III Diptera or Flies. B. Asteidae, Syrphidae and Dolichopodidae. Proc. Hawaiian Ent. Soc. 10: 281-315.

Zimmerman H.G., ERB H.E. \& McFadYen R.E. 1979: Annotated list of some cactus-feeding insects of South America. Acta Zool. Lilloana, 33 (2):101-112.

Received November 6, 2000; revised June 15, 2001; accepted July 30, 2001 